\title{
An Experiential Learning of a Philosophy of Music Education Inspired by the Work of Canadian Composer R. Murray Schafer
}

\author{
Helene Boucher ${ }^{1}$, Tobias Moisey ${ }^{2}$ \\ ${ }^{1}$ Music Department, Arts Faculty, University of Quebec in Montreal, Montreal, Canada \\ ${ }^{2}$ Music Faculty, McGill University, Montreal, Canada \\ Email: boucher.helene@uqam.ca, tobias.moisey@mail.mcgill.ca
}

How to cite this paper: Boucher, H., \& Moisey, T. (2019). An Experiential Learning of a Philosophy of Music Education Inspired by the Work of Canadian Composer R. Murray Schafer. Creative Education, 10, 2111-2131.

https://doi.org/10.4236/ce.2019.1010153

Received: July 19, 2019

Accepted: October 8, 2019

Published: October 11, 2019

Copyright $\odot 2019$ by author(s) and Scientific Research Publishing Inc. This work is licensed under the Creative Commons Attribution International License (CC BY 4.0).

http://creativecommons.org/licenses/by/4.0/

\begin{abstract}
Experiential learning is an educational approach that has been associated with different fields including music education, but rarely with philosophy. Our project consisted of a philosophical experience in action using the work of the Canadian composer R. Murray Schafer. In his Soundscape concept, all sounds in an environment become part of the music that surrounds us. Pre-service student teachers were introduced to his philosophy of music education through experiential learning rather than through a traditional lecture. Additionally, we followed three of them as they taught grades 3, 9 and 11. Our goal was to see to what extent experiential learning of philosophy could be an appropriate pedagogical tool in higher education. Our research question was: How can student-teachers construct their own understanding of a philosophy of music education after having experienced it from the perspective of a student and of a teacher? The following data were examined through collaborative thematic analysis of 1) an open question, 2) their own music composition following Shafer's guidelines, and 3) their experience of teaching the children. Participants were able to explain in their own words the main components of Shafer's view on music education, they described how they could use this vision in their own teaching and they identified specific outcomes (creativity, freedom, motivation and critical thinking) from using this approach. The conclusion was drawn that the experiential learning framework can be an appropriate tool for instructing topics that have traditionally been seen as purely theoretical.
\end{abstract}

\section{Keywords}

Music Education, Philosophy of Music Education, Schafer, Soundscapes, Pre-Service Teachers 


\section{Introduction}

In the field of philosophy of music education, two major views have taken most of the space in the last decades. One of them is the aesthetic vision, a view that Benet Reimer $(1970,2003)$ made a major contribution to, and the other one, developed by (Elliot, 1995; Elliot \& Silverman, 2014) is the praxialist view. In the aesthetic vision, the work of art is at the center of the entire process. The quality of the work and the education of the feelings are believed to lead to the aesthetic experience. Therefore, the education of music emphasises teaching how to listen to music. In the praxialist approach, the central element is the individual and the different roles, musican and listener, he or she has when interacting with music in its context. Other contributors have also elaborated additional views on the topic (Jorgensen, 1997; Wheeler, 2006) which enrich the collective reflection in our field. Jorgensen (1997), in her dialectic philosophy, talks about the difficult choice of creating a philosophy and then trying to apply it to the classroom, or being in the classroom and from that experience, generating a philosophical perspective. She explains how both ways can have their strengths and limits. To echo this questioning and to outline an element that seems to be missing from these enriching conversations, we explored how a philosophy of music education can be learned through an experiential perspective and we documented and analysed such an experience. We are using the work of R. Murray Schafer as a starting point and a structuring element to our contribution.

\subsection{Schafer's Philosophy of Music Education}

Schafer is a major Canadian composer and music educator, environmentalist, scholar and visual artist (Gilmor, 2015). He is well-known for his World Soundscape Project that investigated the acoustic environment and how people react to it. His philosophical vision, the acoustic ecology, proposed that we hear "the acoustic environment as a musical composition and, further, that we own responsibility for its composition" (Schafer, 1977: p. 205). He referred to the soundscape as "an acoustic environment consisting of events heard, rather than objects seen" (Schafer, 1977: p. 7).

Schafer's music education goal can be understood as the development of a "sonological competence". Wrightson (2000) describes Schafer's realisation of the incredible dominance of the visual modality in society, or "eye culture", as the starting point of his teaching process. He believed that children were losing the ability to listen and he argued for the development of listening skills to become an integral part of the national curriculum. In addition to working with students to develop this ability, he published different educational books presenting his vision: The Composer in the Classroom (1965), Ear Cleaning (1967), The New Soundscape (1969), and Rhinoceros in the Classroom (1975).

Kern (2007) resumes his philosophy of music education as "going beyond formal music training, challenging music educators to include all forms of arts 
into the curriculum rather than separating them. Schafer believes that everyone can make music, and that participation in "multimedia" art projects (including singing, dancing, painting, etc.) provides a unique, integrating and holistic experience".

In order to promote multimedia projects, Schafer developed three educational tools: graphic notation, soundscapes, and "ear cleaning" (Canadian National Art Center, 2016: p. 4).

"GRAPHIC NOTATION refers to music that is written down in non-traditional ways. Instead of notes lined up neatly on a staff, there are swirls, colours, pictures, scattered notes and musical symbols, or other elements of drawing or calligraphy meant to express the sound and character of the music.

A SOUNDSCAPE is a sound or combination of sounds that forms or arises from an immersive environment. Schafer's definition of soundscape includes all of the sounds from a particular environment that reach the human ear. He considers that we are linked to the natural world through its voice.

EAR CLEANING describes the process of listening carefully and noting all of the diverse sounds in one's environment, as opposed to taking background sounds for granted".

Schafer's philosophy of music education is presented in "The Musical Soundscape Unit" (Schafer, 1986: p. 243) and involves three principles:

1) Try to discover whatever creative potential children may have for making music of their own.

2) To introduce students of all ages to the sounds of the environment; to treat the world soundscape as a musical composition of which man is the principal composer, and to make critical judgments which would lead to its improvement.

3) To discover a nexus or gathering-place where all the arts may meet and develop together harmoniously.

\subsection{Goal and Research Questions}

The goal of this qualitative inquiry was to explore how pre-service teachers could be introduced to a philosophy of music education through an experiential approach rather than through a theoretical one. The project emerged from an invitation to participate in an arts education collaborative exploration involving a major Canadian University's faculty of education, a national museum of fine arts, and local partner schools. Our project named "Soundscape-A Follow-Up Experience to R. Murray Schafer's Soundscapes”, involved student teachers enrolled in a music education program and generalist student teachers (registered in an introductory course on music teaching). These student teachers would be completing their final field experience within the same semester.

As the project was unfolding, it became clear that we had to document its process and try to get an understanding of what it can mean for student teachers to "experience" a philosophy of music education rather than just be presented with different views in a typical university course mostly through lectures and readings. The research questions that emerged were: How can student-teachers 
construct their own understanding of a philosophy of music education through experiencing it from the perspective of a student and of a teacher? Following these experiences, how can student teachers understand and articulate Schafer's view of music and music education? How might learning about this philosophy of music education influence their future teaching?

\section{Methodology}

\subsection{Theoretical Framework: Experiential Learning Theory}

This research uses as theoretical framework (Kolb \& Kolb's, 2005, 2017; Kolb, 1984) experiential learning theory which is built on the writings of important scholars in the field of teaching and learning such as John Dewey, Kurt Lewin, Jean Piaget, William James, Carl Jung, Paulo Freire and Carl Rogers. It is structured around the following six propositions: 1) Learning is best conceived as a process, not in terms of outcomes; 2) All learning is relearning; 3) Learning requires the resolution of conflicts between dialectically opposed modes of adaptation to the world; 4) Learning is a holistic process of adaptation to the world; 5) Learning results from synergetic transactions between the person and the environment; 6) Learning is the process of creating knowledge.

Kolb \& Fry (1975) also created a model called the learning cycle that should be understood as a continuous spiral. In this model, four elements are experienced by the learners: 1) concrete experience followed by 2) observation and experience followed by 3) forming abstract concepts followed by 4) testing in new situations. Kolb \& Kolb (2017) suggest that "immediate or concrete experiences are the basis for observations and reflections. These reflections are assimilated and distilled into abstract concepts from which new implications for action can be drawn. These implications can be actively tested and serve as guides in creating new experiences".

Russell-Bowie (2013) used this same framework for a study on preservice generalist teachers and their experience learning to teach music to primary school children in Australia. Following their positive results, they recommend that preservice music/arts education programs could include all four stages, inspiring students to teach music and giving them the training, skills and experiences, changing their attitudes and developing their confidence and competence in relation to music teaching.

To anchor our research in Kolb and Kolb's experiential learning, we designed it within the four elements of the learning cycle as applied by Russell-Bowie (2013) in the context of music education.

Stage 1: Concrete Experience-variety of experiential learning activities

In class activities included: listening to surrounding sound followed by conversation and creative notation of those sounds (ear cleaning activity); sound exploration with different types of papers and collective creation and notation of a soundscape; Listening to Shafer's Once on a Windy Night and discussion about the work, feelings and notation. In groups of 4 to 5 , students composed their 
soundscape and come up with a visual representation of it using a large sheet of paper, colour pencils, pastels, crayons, coloured papers, glue, etc. Creations were presented to classmates and notation explained. Students discussed their own creation process.

Stage 2: Reflective Observation-opportunity for students to reflect on their learning

Students were asked to fill out the first questionnaire and to reflect on their experience.

Stage 3: Abstract Conceptualisation-students are being challenged to relate their observations, experiences and reflections to relevant classroom and arts education pedagogies

Students were asked to share their experience and to link their reflection with previous learning experiences and knowledge.

Stage 4: Active Experimentation-students have the opportunity to test these in relation to an authentic classroom situation

Student-teachers went to their field experience and had the opportunity to replicate the lesson with the children in their classroom. Stage 2 was then repeated when they were asked to fill out the second questionnaire and provide us with their reflective observations.

\subsection{Research Sites and Participants}

Our research was done in two phases: first, in a major Canadian university and second, in elementary, middle and high schools. The sample size of student-teachers for phase 1 was 36, where in phase 2 it was 3 student-teachers and 50 children from grades 3 to 11 . Since the second phase of the research was to look in more depth into the experience of the student-teachers and their own students, much smaller sample size was needed due to the qualitative nature of the data analysis. Participants for phase 2 were recruited from the participants in phase 1 on a voluntary basis. The number of children in each group varied. Children were invited to participate, and parental approval was requested. The numbers show a greater interest from the children in grade $3(n=20)$ and $9(n=20)$ than in grade $11(n=10)$. Due to the qualitative nature of our research, this was not deemed detrimental to the data analysis.

Phase 1:

The first group of participants-Canadian University: Students in the Kindergarten and Elementary School Education $(n=23)$ (designated as Generalists Teachers) registered in the course Music Curriculum and Instruction and doing their last field experience immediately after the end of the semester.

The second group of participants-Canadian University: Students in the Music Education Program $(\mathrm{n}=13)$ (designated as Music Specialists) registered in the course Music Methods II and doing their final field experience immediately after the end of the semester.

Phase 2:

Elementary School in a suburban area-One music specialist student teacher 
(Amber*) and a class of grade $3(n=20)$.

Middle School in a suburban area-One music specialist student teacher $\left(\operatorname{Mark}^{\star}\right)$ and a class of grade $9(\mathrm{n}=20)$.

High School in an urban area-One music specialist student teacher $\left(\mathrm{Nicole}^{\star}\right)$ and a class of grade $11(\mathrm{n}=10)$.

${ }^{*}$ Names have been changed to preserve confidentiality.

\subsection{Data Collection}

Participants were asked to comment on their experiences on two occasions: after experiencing the lesson as students and after experiencing the lesson as teachers. The first one consisted of collecting comments from our participants anonymously, in an open-ended way. They were given the following instructions and answered individually in writing, immediately after being taught the lesson: Comment on your experience as a participant in re-enacting Schafer's Soundscape. The second consisted of specific questions focusing on their experience as teachers.

The lessons were videotaped to allow for close observation of our participants in their dualistic role as students and teachers and to allow for a description of their experience through thematic analysis and retelling of anecdotes. Since art can also be a source of information (Van Manen, 1997: p. 74), the creation process of the musical and visual work, the work of art itself, and the description made by the creators became an important part of our data. Therefore, several types of data were collected as presented in Table 1: videotapes of the lessons, videotapes of the musical compositions, visual representations of the compositions, explanations given by the students about their musical compositions and visual representations and, the written comments of the participants about their experience of the soundscape lesson or the follow-up questionnaire after teaching the soundscape lesson.

\section{Results}

\subsection{Data Analysis}

In qualitative research, thematic analysis is largely used as a methodological approach. To perform the thematic analysis, the researchers chose not to use any computer program, but to rather work collaboratively in identifying themes and then in making sense and creating meaning from them. They individually looked at all sentences or clusters of words and tried to identify what they were conveying about the participants' experience. Afterwards, the researchers compared their analysis and came to an agreement about the themes that emerged. The following results are reported according to the different data collected: questionnaires, soundscapes created by the students and videotaped lessons.

\subsection{Thematic Analysis of Questionnaires}

The analysis of the questionnaires was organized according to three main 
Table 1. Time line of events and type of data collected during each event.

\begin{tabular}{|c|c|c|c|c|c|}
\hline Events & \multicolumn{5}{|c|}{ Type of Data Collected } \\
\hline \multicolumn{6}{|l|}{ Phase 1} \\
\hline $\begin{array}{l}\text { Researcher taught } \\
\text { soundscape lesson to the } \\
\text { generalist teachers }\end{array}$ & $\begin{array}{l}\text { Lesson } \\
\text { (videotaped) }\end{array}$ & $\begin{array}{l}\text { Performance of } \\
\text { musical compositions } \\
\text { (videotaped) }\end{array}$ & Visual representations & $\begin{array}{l}\text { Explanations of } \\
\text { musical compositions } \\
\text { and visual } \\
\text { representations }\end{array}$ & $\begin{array}{l}\text { Written comments } \\
\text { describing the } \\
\text { participant's experience } \\
\text { of the soundscape } \\
\text { lesson }\end{array}$ \\
\hline $\begin{array}{l}\text { Researcher taught } \\
\text { soundscape lesson to the } \\
\text { music specialists }\end{array}$ & $\begin{array}{l}\text { Lesson } \\
\text { (videotaped) }\end{array}$ & $\begin{array}{l}\text { Performance of } \\
\text { musical compositions } \\
\text { (videotaped) }\end{array}$ & Visual representations & $\begin{array}{l}\text { Explanations of musical } \\
\text { compositions and visual } \\
\text { representations }\end{array}$ & $\begin{array}{l}\text { Written comments } \\
\text { describing the } \\
\text { participant's experience } \\
\text { of the soundscape } \\
\text { lesson }\end{array}$ \\
\hline \multicolumn{6}{|l|}{ Phase 2} \\
\hline $\begin{array}{l}\text { Nicole } \\
\text { Music specialist taught } \\
\text { soundscape lesson to } \\
\text { gr. } 11\end{array}$ & $\begin{array}{l}\text { Lesson } \\
\text { (videotaped) }\end{array}$ & $\begin{array}{l}\text { Performance of musi- } \\
\text { cal compositions } \\
\text { (videotaped) }\end{array}$ & Visual representations & $\begin{array}{l}\text { Explanations of musical } \\
\text { compositions and visual } \\
\text { representations }\end{array}$ & $\begin{array}{l}\text { Follow-up questionnaire } \\
\text { filled up by Nicole }\end{array}$ \\
\hline $\begin{array}{l}\text { Mark } \\
\text { Music specialist taught } \\
\text { soundscape lesson to gr. } 9\end{array}$ & $\begin{array}{l}\text { Lesson } \\
\text { (videotaped) }\end{array}$ & $\begin{array}{l}\text { Performance of } \\
\text { musical compositions } \\
\text { (videotaped) }\end{array}$ & Visual representations & $\begin{array}{l}\text { Explanations of musical } \\
\text { compositions and visual } \\
\text { representations }\end{array}$ & $\begin{array}{l}\text { Follow-up questionnaire } \\
\text { filled up by Mark }\end{array}$ \\
\hline $\begin{array}{l}\text { Amber } \\
\text { Music specialist taught } \\
\text { soundscape lesson to gr. } 3\end{array}$ & $\begin{array}{l}\text { Lesson } \\
\text { (videotaped) }\end{array}$ & $\begin{array}{l}\text { Performance of } \\
\text { musical compositions } \\
\text { (videotaped) }\end{array}$ & Visual representations & $\begin{array}{l}\text { Explanations of musical } \\
\text { compositions and visual } \\
\text { representations }\end{array}$ & $\begin{array}{l}\text { Follow-up questionnaire } \\
\text { filled up by Amber }\end{array}$ \\
\hline
\end{tabular}

themes and their subthemes (see Table 2). The first theme was the development of a philosophical understanding, the second focused on the impact this experience could have on the participants' act of teaching and finally, outcomes that can be generated by using this approach.

The sub-themes that emerged from the questionnaires were first labeled according to the participants' own words. It is only after organizing the data that links were made by the researchers to connect the subthemes to Schafer's words. The philosophical perspective's sub-themes were: the omnipresence of sounds, the definition of what is music, and the connections between the sound and the visual. The act of teaching was divided according to the exploration by the student-teachers in their own teaching, the use of teamwork, and their own learning process. Finally, the third main theme, outcomes, was organized according to the sub-themes of creativity, freedom, motivation and critical thinking.

The following sections will show how the participants' answers and Schafer's writing connect. To do so, excerpts from Schafer's publications will be used to present the main ideas of his philosophy. Each theme and sub-theme will also be illustrated with quotes from the participants' questionnaires to support the categorisation. (The participants have been identified with an alpha numeric code- "G" stands for the generalists, " $\mathrm{S}$ " for music specialists, and the names are those of the three music specialists who took part in the second phase of the study.) Additionally, this presentation of the data will underline how the student teachers' experiences resonate with Schafer's vision. 
Table 2. Primary and sub-themes that emerged from the questionnaires.

\begin{tabular}{|c|c|c|}
\hline \multirow[t]{2}{*}{ Primary Themes } & \multicolumn{2}{|c|}{ Sub-Themes } \\
\hline & Participants' Words & Schafer's Words \\
\hline \multirow[t]{3}{*}{ Philosophical Perspective } & Omnipresence of Sounds & Acoustic Ecology \\
\hline & Definition of Music & Architecture of Sounds \\
\hline & Sound and Visual Connections & Multimedia Art Projects \\
\hline \multirow[t]{3}{*}{ Act of Teaching } & Exploration in my own teaching & $\begin{array}{c}\text { Development of Sonological } \\
\text { Competence }\end{array}$ \\
\hline & Team Work & Community of Learners \\
\hline & Learning Process & $\begin{array}{c}\text { Ear Cleaning, Soundscape } \\
\text { Graphic Notation }\end{array}$ \\
\hline \multirow[t]{4}{*}{ Outcomes } & Creativity & \\
\hline & Freedom & $\begin{array}{l}\text { Building citizens in an ideal } \\
\text { democracy }\end{array}$ \\
\hline & Motivation & \\
\hline & Critical Thinking & \\
\hline
\end{tabular}

\subsubsection{Philosophical Perspective}

\section{1) The Omnipresence of Sounds/The Acoustic Ecology}

For Schafer, the acoustic ecology is of primary importance. Acoustic ecology can be understood as a discipline studying the relationship, mediated through sound, between human beings and their environment (Wrightson, 2000). It also implies that one tries to hear the acoustic environment as a musical composition (Schafer, 1977: p. 205). On the other hand, it is often linked to sound pollution and an increase in technological sounds versus the decrease in natural sounds throughout human history. According to Schafer (1973: p. 28), we would be surrounded today with $6 \%$ of natural sounds, $26 \%$ of human sounds and $68 \%$ of technological sounds, the proportional reverse of primitive society.

In reaction to this phenomenon, Schafer himself decided to live on a farm in a rural area of Ontario, Canada, in search of what he calls Hi-Fi Soundscape (Gilmor, 2015).

A hifi-system is one possessing a favourable signal to noise ratio. The hi-fi soundscape is one in which discrete sounds can be heard clearly because of low ambient noise level. The country is generally more hi-fi than the city; night more than day; ancient times more than modern. In a lo-fi soundscape, individual acoustic signals are obscured in an over dense population of sounds. Perspective is lost. On a downtown street corner there is no distance; there is only presence (Schafer, 1973: p. 11).

In our study, the student teachers seemed to become aware of this omnipresence of sound. The ear cleaning activities and the creation of the soundscapes seem to have created this realization. They reported both positive and negative elements of their perception of sound.

It was interesting to listen to sounds that are always present but that we never really take the time to experience (G4). 
I love being able to represent everyday sounds we do not normally "listen to" (G5).

It reminded me of a time someone told me, "I love the sound of camp" (G11).

It made me want to create something calming because of all the sound pollution I hear in my everyday life (G3).

So often we are bombarded with sound and visual stimuli in our daily lives, but rarely is this a gentle, inspiring experience (G16).

\section{2) Definition of Music/Architecture of Sounds}

Schafer argues that music has been defined by the Greeks from two different angles, first as subjective emotion and second as "sonic properties in the materials of the universe" (Schafer, 1973: p. 4). He claims that the first view dominated the western musical heritage in putting emphases on expression, tone colours, tempo and dynamic variations making it a "subjective and irrational art of the virtuoso artist". He chooses the second approach: "a reaffirmation of music as search for the harmonizing influence of sounds in the world around us". Or as John Cage puts it: "Music is sounds, sounds heard around us whether we're in or out of concert halls" (cited in Schafer, 1973: p. 4).

Our participants showed an understanding of Schafer's vision of music.

It makes me appreciate the sounds around us and the concept that anything organized in some way, shape, or form can be considered music (S3).

Through Schafer's work and through completing this lesson based on soundscapes, my understanding of Schafer's philosophy is that he believes in the idea of music not being a formal entity. Music as most of us have learned has always been formal in terms of notation, theory, instruments, performance practice and more (Mark).

Schafer takes us outside of this closed-off perception to view music in an abstract light, as he breaks music down to what it truly is-organized sound. Mark

I really love this lesson because too often musicians are hyper-focused on the nitty-gritty details of technique and reading the score, so this gives them an opportunity to step back and appreciate music for what it is-an organized body of sound (Nicole).

\section{3) Sound and Visual Connections/Multimedia Art Projects}

Kern (2007) explains how Schafer's philosophy of music education encompasses more than just the traditional formal learning of music, but that it rather connects the different arts through multimedia art projects. His work as a composer reflects this vision where his musical scores often include some pictorial representation of sounds in combination with elements of the formal notation.

These connections seem to have been recognised as an interesting and new element by our participants.

I found it interesting to hear others' perspectives on how to develop sounds and see the images they associated with these sounds, but also how far students can go to create something truly unique, size, color, thickness, etc. (S2).

I also enjoyed listening to everyone's pieces and hearing how they drew their soundscapes. I think it is a unique experience to show music in a different light 
( G12).

Interesting to think about how sounds may be transformed into visual representations and how these representations change and morph (and may even take on colour) and the sounds change and grow (G14).

\subsubsection{Act of Teaching}

1) Exploration in My Own Teaching/Development of the Sonological Competence

According to Schafer, the sonological competence, or the ability to listen, should be developed in children as an integral part of the national curriculum (Wrightson, 2000). To foster this ability, he created practical teaching activities called "ear cleaning", among which: the creation of a list of any five environmental sounds (not music) that you remember hearing today; and a list of five sounds (not music) you like and five you do not; "sound walks" a walking meditation where the object is to maintain a high level of sonic awareness (Schafer, 1969). This sonological competency is also reflected in Schafer's work, for example, Music for Wilderness Lake is performed by 12 trombonists positioned around an untouched lake in the wilderness, playing meditative music at dusk and dawn while nature contributes with environmental sounds" (Kern, 2007).

Our future teachers, while experiencing the creation of their own soundscape were clearly aware of the teaching potential of this approach and of the benefits their students could gain from it.

Throughout the experience, I listened with two minds. Primarily, I was focused on the music, the learning, etc. but my brain was also checking for how I could repeat it for future classrooms in a teaching capacity (G20).

In removing the boundaries of rules and restrictions, music teachers can allow their students to think outside the box and take their music learning in directions they did not expect to go (Amber).

I now feel that we are constraining our students too tightly by giving them so many rules to follow and limitations to remain within. This makes them feel like they are unable to contribute to music along with self-expression, resulting in future musicians who are afraid to even improvise let alone try to create something of their own (Amber).

One of my groups in another class created a representation of the sounds at home on her farm. This one was very interesting and included narration of the different "movements" as they called it, which the team of students came up with completely on their own. They used classical structure in their abstract thinking in combining her feelings of the familiar sounds of life growing up on the farm (Amber).

\section{2) Team Work/Community of Learners}

Schafer's vision of education is based on the idea of lifelong learning; therefore, the teaching and learning is a relationship that goes in two directions: the students learn from the teacher and the teacher learns from the students. He speaks of a "community of learners" in which collaborative learning, inquiry, 
creativity, reasoning skills and construction of knowledge are put forward (Rutherford, 2014). The music specialists in our inquiry noted that teamwork was a novel aspect of this approach. It is interesting that this theme was not mentioned at all by the generalist teachers. A hypothesis for this difference might lie in the fact that the music specialists are trained in a more individualistic way, through the learning and practicing of an instrument, whereas the Bachelor of Education puts lots of emphasis on cooperative work.

I also liked that the creation activity was done in teams because we could get inspired by other's ideas ( $S 4)$.

It seems to be very educative too, as children (on our place) would have to exercise not only their creativity but team working, appreciation of each other's ideas (S5).

It was interesting doing this in a group as I definitely would have come with completely different ideas on my own. The collaboration was great and allowed for a greater range of sounds and ideas (S8).

\section{3) Learning Process/Ear Cleaning, Soundscape, Graphic Notation}

Schafer, although well known as a composer, is also recognized for his new and creative way to explore the learning of music in the schools. He published many books that present concrete activities to include in the classroom. He encourages children to explore how they can be creators and find sounds from unusual sources (Canadian National Art Center, 2016). Three elements are present in many of his activities: ear cleaning, creation of soundscape and invention of graphic notation. Here is how he views the role of the teacher: "The best thing any teacher can do is to plan the spark of a subject in the minds of his students, so that it may grow even if the growth takes unpredictable forms" (Schafer, 1975b: p. 6). Our participants reported how they felt these activities were engaging for their students, but also how unusual this learning process was for them and for their students who are used to being directed at all times.

I enjoyed that the students were actively engaged in the learning process in the sense that they were the judges, creators, storytellers, presenters and teachers of their process. In this lesson, they lived it (Amber).

I really enjoyed seeing my students getting more and more engaged as the lesson progressed. It made me so happy to see them discussing and creating during their group work, all the while having fun (Nicole).

Hearing the students talk about the sounds around them as they proved to be keen listeners. Hearing their choice of vocabulary to describe certain sounds as these choices were well articulated. Seeing the process of most of the groups and the creative ideas coming from students who do not necessarily thrive in a formal music environment (Mark).

My students were not used to this type of learning situation. They are very comfortable with group work and playing/composing music together, but they were not used to having all that freedom. Normally, their composition projects consist of either making up notes or rhythms, over a guided section of music using concepts they have already learned (Amber). 
There was a bit of laziness/lack of drive from some of the groups as mentioned, but for the most part all of the students participated exceptionally well. I was especially inspired by a group that included the top student in the class and a student that has a learning disability. Instead of taking over the group and telling the student what to do, the skilled student took the ideas of the other student and the rest of the group, and facilitated in such a way to keep the group on task and create something truly remarkable (Mark).

Additionally, our participants commented at length about their emotional state throughout the learning process. This seems to be, however, a topic that Schafer did not address much in his writings. Several of them mentioned a joyful feeling during the creating experience and the listening of their peers' creations. Others also talked about some nervousness or fear at the beginning of the project, but finally experienced a sense of relief coming from the freedom that is an integral part of these activities.

I enjoyed participating in this re-enactment because we were allowed to add our own creative spin to it and choose instruments that we were comfortable with. It was a fun activity to complete as an adult and I am sure it is just as fun for younger students $(G 8)$.

I enjoyed listening to other teams' soundscapes ( $G 7)$.

It was a lot of fun to come up with ideas and figure out how to represent that visually on the paper (S8).

I also like how it's up to us how we want to visually represent, as some students might feel very scared if they hear that they have to draw $(S 3)$.

The students can experiment with multiple musical elements without any fear of being judged ( $S 7$ ).

It can be abstract and take on several shapes and forms, and this mindset allows students to openly create without the sense of failure-a feeling that is unfortunately all too common for some students (Mark).

\subsubsection{Outcomes: Building Citizens in an Ideal Democracy}

schafer's goals in terms of music education are broader than other philosophers. He talks about creativity and the importance of reaching communities. Kern (2007) reports Schafer's words: "It has to do with a much wider area than just music education. It's building citizens, I guess in an ideal democracy". Although our participants didn't mention this idea of developing citizens, they were aware of a larger vision and the importance of developing the whole person.

This style of lesson, and Schafer's philosophy as a whole, teaches students about creativity, timbre, teamwork, expression and so many other aspects that we as music teachers try to teach every day (Mark).

Four specific outcomes were reported by our student teachers: creativity, freedom, motivation and critical thinking.

\section{1) Creativity}

The more we carried on, the more I realize the infinite number of possibilities (S3). 
Your creative thinking expands, and I feel like I started to image things more (G15).

It was a great opportunity to be creative and explore ways that our everyday sounds can be composed into, in this case, a soundscape, forcing us to think outside the box (G17).

...seeing the process of most of the groups and the creative ideas coming fromstudents who do not necessarily thrive in a formal music environment... (Mark).

\section{2) Freedom}

I felt that this experience was very liberating. Instead of feeling like you must stay within limitations we were given complete freedom to create (S6).

The students can experiment with multiple musical elements without any fear of being judged. This applies for the composition process and the performance (S7).

Students had to go "loose" in order to be creative (S5).

The use of having the students use whatever symbols they chose as notation for their sounds and compositions gives them the liberty to try different things without the stress of knowing how to write it down, they just simply had to represent it. Amber

We, as a society, are so accustomed to following strict rules and regulations that we lose sight of the target when given too much freedom. In attempting to help them, I found myself at times guiding them towards an idea or giving them examples to use, which in turn defeated my purpose of letting them free their minds and do it themselves (Amber).

Once again, I believe that their stage of development in terms of adolescence, as well as their familiarity with formal music education played a role in this as groups were less willing to step outside of their comfort zone (Amber).

3) Motivation

Not only was this eye (or should I say ear opening), but also, I was engaged and motivated to explore the entire way (S3).

Making the lesson both interesting and stimulating (Amber).

I feel it gave them a sense of power and entitlement to be able to be their own creators.

When they get to share their creations with their classmates and teachers it gives them a huge sense of satisfactory and accomplishment (Amber).

\section{4) Critical Thinking}

Rutherford (2014) reports how Schafer feels his exercises can help the students develop critical thinking. In The Thinking Ear (Schafer, 1986: p. 244), he says, "could music not be taught as a subject which simultaneously releases creative energy and trains the mind in the perception and analysis of its own creation?" Our participants felt that the answer to this question was a positive one, both for themselves and for their students.

It forced me to think critically using my musical knowledge ( $G 5)$.

A great way to mix critical thinking and music (G15).

Students should actively listen and critically think about the sounds around us, and treat the environment as a foundation for musical composition (Nicole). 
This lesson is fantastic because it combines both visual arts with musical expression, on top of fostering mindful listening and critical thinking (Nicole).

\subsection{Thematic Analysis of the Soundscapes Created by the Students}

The next part of our analysis focused on the soundscapes themselves, both the sound and the visual elements, created by our participants. These works of art were analysed according to the themes the participants chose to represent during their creative experience. They were then organised according to four categories: sounds of nature, sounds in everyday life, storytelling and abstract art.

The sounds of nature showed the most thematic interest with 13 pieces, and the idea of the rain (rainforest, wind, storm) was the most frequently depicted. Other elements of nature were the snow, volcanos, night time and day time. Interestingly, the theme of the rainforest was present in gr. 9, gr. 11, generalists and music specialists.

The sounds from the participants' everyday life were chosen for seven creations. They varied according to the different age groups and the reality of their own life. For a group of third graders, it is about playing with their kitties, whereas for the high school students it was the sound illustration of their cafeteria at lunch time or their transit in the city bus. The undergraduate students also described public transit, but for them it was the subway, while others focused on their field experiences in the school, depicting their classroom and the playground. Others chose to explore their private life, illustrating their bed time, from their use of the toilet, to the nightmare they had and the sound of somebody snoring.

A group of grade 9 students took a very different approach and came up with a creative story of a German cat going through some adventures: falling down, slowly getting back up, getting going again and then speeding up.

Two groups of third graders decided to take a more abstract approach, creating a series of organised sounds and titled their work according to those sounds: Boom 12 (because they made 12 sounds) and Tam tamtam (because they mainly used hand drums to produce their creation). Two other pieces, both created by the youngest students, although titled in a very descriptive way, were not organised to a theme and were included in the abstract art category (Table 3).

To continue our parallel with Schafer's (1977) wording, we could also categorise the soundscapes according to the acoustical environment they reproduce.

Biophony and Geophony: natural sounds, animal vocalizations, sounds of weather (14 soundscapes fit this category).

Anthropophony: environmental sounds created by humans including musical composition, sound design as well as sounds from industrial technology (11 soundscapes fit this category).

\subsection{Analysis of Videos of the Lessons}

Videos of the lessons, although not systematically analysed, were used to supplement 
Table 3. Themes and titles of soundscapes by grade levels.

\begin{tabular}{|c|c|c|}
\hline Themes & Title of Soundscape & Grade Level \\
\hline \multirow[t]{13}{*}{ Sounds of Nature } & La Neige & 3 \\
\hline & Natural disaster & 9 \\
\hline & Volcanic sharks & 9 \\
\hline & Lullaby of night & 9 \\
\hline & Rainforest & 9 \\
\hline & Wind and the sky & 9 \\
\hline & Raining night & 11 \\
\hline & Tropical Paradise & Generalists \\
\hline & Days End & Generalists \\
\hline & Morning Garden & Generalists \\
\hline & Tarzan Gorilla Dad & Generalists \\
\hline & The Storm & Generalists \\
\hline & Ka Ka Doo & Music Specialists \\
\hline \multirow[t]{7}{*}{ Sounds in Everyday Life } & Les chatons & 3 \\
\hline & Bus & 11 \\
\hline & Cafeteria at lunch & 11 \\
\hline & Summer in the Playground & Generalists \\
\hline & Bed Time & Generalists \\
\hline & Bonaventure Subway & Music Specialists \\
\hline & High School Brains & Music Specialists \\
\hline Storytelling & A cat from Germany 5 & 9 \\
\hline \multirow[t]{4}{*}{ Abstract Art } & Le chien Zombie & 3 \\
\hline & Les fantômes & 3 \\
\hline & Tam tamtam & 3 \\
\hline & Five Nights at Freddy's-Boom 12 & 3 \\
\hline
\end{tabular}

our understanding of our participants' lived experience. We observed how both the student teachers and children reacted when presented with the idea of listening to the sounds surrounding them, or in Schafer's words, the development the sonological competence.

It is interesting to note that the different groups of participants, when proposed to listen to the sounds around them, identified many similar ones. Among those, we noted: ventilation, breathing, cars, markers, chairs moving, footsteps, talking. Therefore, it seems possible that these are descriptors of the acoustic ecology of Canadian classrooms. When grade 9 students were invited to discuss this idea of the omnipresence of sounds, one of them said: "I didn't know this before and I didn't care". This is certainly leading us to believe that he came to a realisation. This is being reinforced by Nicole (student teacher to grade 11): 
"Music can be anywhere. We can make music just out of paper".

The participants in our study were asked to work in small groups to create and present their soundscapes. Overall, the teamwork was highly cooperative leading to the development of a community of learners. Most groups were very interactive and chose an egalitarian approach. However, in a grade 11 group, we observe that they chose to designate a conductor to perform their soundscapes, therefore naming an "official" leader while the other group members were the "musicians". The collective work was a little bit more challenging for our younger children. Among the third graders, we could witness a group where one boy took all the decisions for the composition, the instrumentation to be used, who was to play and when. The other members of the group passively followed his indications. This is likely to be linked to a developmental issue since cooperation is a learned skill that is not fully developed by age 8. In fact, studies have shown that even though children start to demonstrate pro-social and helping behaviors by age two (Eisenberg \& Fabes, 1998; Warneken \& Tomasello, 2006), some evidence of reciprocity effects are observable in a stronger way in elementary school (Harris, 1970; Staub \& Sherk, 1970). Moreover, Cloutier, Gosselin, \& Tap (2005: p. 374) suggests that this is a complex developmental process that continues until adulthood.

Regarding the learning process, we observed how most of the participants developed their own graphic notation. Once again, there seems to be a developmental issue at work. The younger children, used some symbols that were proposed by the teacher, organised them and completed their creation with their own ideas. Whereas, the generalist student teachers created their own symbols and many of them created a global impression that expressed their soundscapes. For example, a group drew a landscape with a sunset and titled it: Day's End. The music specialists structured their creations similarly to a traditional musical score with a time line, elements of forms, dynamics and tempo. Their creations were much longer and their musical ideas were developed. This supports the three-stage creativity development theory of Gardner, Phelps, \& Wolf (1990) in which development is divided between the pre-conventional, conventional and post-conventional stages. In the pre-conventional stage, the child is independent of the culture, explores symbolic media in his or her own way and tries to find solutions on his or her own. During the conventional stage, the child becomes sensitive to "culture dictates", aims to produce symbolic products in the way adults do and conforms to conventions. This is clearly the stage where our 3rd graders are. The post-conventional stage demands a critical attitude toward conventions, the creative person no longer contents their self with imitating but pursues their own ends. Gardner, Phelps, \& Wolf (1990) argue that many adolescents give up creative work at this point and concentrate solely on reception. Although, it is obvious that the music specialists were in the postconventional stage, it is not so obvious for the teenagers in our studies. They were the ones who needed strong encouragement to pursue the task, indicating that it would have been easier for them to be only receptors of music rather than creators. The 
creations of the grade 9, grade 11 and generalist students were all very similar in terms of ideas, duration and conventional depiction of sounds. This also seems to support Gardner, Phelps, \& Wolf's (1990) theory, in which some will keep on developing their creative potential while others will stagnate in the conventional stage.

Among the different outcomes that were mentioned by our student teachers, we could observe how creativity was present in various ways: in the stories the students chose to depict, in the way they used usual objects to create sounds, or in using traditional instruments in unusual ways like blowing in a tuba to get the sound of the wind. We also can note that all of them moved away from traditional notation, even if for some of them, this was a challenge. Nicole, student teacher for grade 11, worked with a group of Chinese students who seemed particularly shaken by the idea of creating music in this different context. She later commented on this: "Even I am foreign to this kind of learning situation, let alone my students! It is particularly difficult for students brought up in Asian education systems because there is less focus on artistic creation, improvisation, and exploration compared to the Canadian education system" (Nicole).

In regard to motivation, we can note that all groups came up with a final product and were on task most of the time. From the videos, we could observe a few off-task behaviors and they were observed mainly in the grade 9 class, where the teacher had to bring them back on track. "Inspiration for some of the groups was a bit of a challenge as it took quite a bit of pushing and prodding to get some of the students going. Once again, I believe that their stage of development in terms of adolescence, as well as their familiarity with formal music education played a role in this as groups were less willing to step outside of their comfort zone and experiment with no fear of failure" (Mark).

Finally, through the videos, an element that is highly visible is the pleasure and joy that this activity created. The entire process, for all age groups, was filled with smiles, laughter, enthusiasm and strong engagement in the activities.

\section{Discussion}

Our qualitative study looked at the experiential learning of Schafer's philosophy of music education by student teachers. Our goal was to see to what extent the experiential learning of philosophy could be an appropriate pedagogical tool in higher education.

\subsection{Research Questions and Findings}

Our original question was: "How can student-teachers construct their own understanding of a philosophy of music education after having experienced it from the perspective of a student and of a teacher?" Our observations lead us to affirm that for Schafer's philosophy, and in our specific context with student teachers, they were able to grasp the main ideas of this philosophy of music education and to identify them in their own words. Therefore, the role of the professor is to make the learning conscious by labeling the concepts according to the authors' 
words, and help the students make links between their experiences and those concepts.

To the question, "Following the lived experience, how can student teachers understand and articulate Schafer's definition of music?" We were able to show how accurate the student teachers were in identifying the main elements of this vision. Schafer talks about an architecture of sound in the world around us and our participants understood and explained it as music that lives outside of its traditional formal entity.

Our third question was labeled as follows: How does learning about a philosophy of music education influence their future teaching? To answer this question, here are the direct quotes of the three music specialists who took part in both phases of the research.

I do in fact feel that my approach to music education has been significantly influenced by Schafer's philosophy of music education (Amber).

I have adopted Schafer's philosophy that we should foster the creative potential that all students have regardless of their age and musical experience (Nicole).

This experience is fun, and opens students' minds to the fact that music does not have to be a formal entity. It can be abstract and take on several shapes and forms... This lesson will stick with me for years and I am already looking forward to using it to inspire creativity and expression in my future students (Mark).

We mentioned earlier how Jorgensen (1997), in her dialectic philosophy, talks about the difficult choice of creating a philosophy and then trying to apply it in the classroom, or being in the classroom and from that experience, generating a philosophical perspective. She explains how both ways can have their strengths and limits. We would like to offer a third way of looking at this question. Through our analysis, we showed how the understanding of a philosophy and its application through the act of teaching can happen simultaneously, therefore generating concrete outcomes. So, maybe this process could also be applied in the creation of a philosophical perspective; that the construction of the philosophical ideas could happen during the act of teaching and that act of teaching can then nourish the philosophical reflection. Creating a series of exchanges between reflection and practice would give birth to a truly thought-out and applicable philosophy of education.

\subsection{Limits}

This research used a qualitative method and therefore, the findings are not generalizable to a population. However, they are likely to be transferable to student-teachers within a similar context.

It is also important to note that our inquiry only looked at one philosophical approach, Schafer's, which is by its nature very "hands on". Consequently, it might not be possible to use an experiential approach with other philosophies of music education and our results could be only applicable to the studied philosophy. 
Similarly, due to the very nature of music that is experiential (whether as a listener, composer or performer), these results might not be applicable to other fields of study. This research does not permit us to state that all intellectual learnings could be achieved successfully through experiential learning.

\subsection{Future Research}

More research is needed to better understand the process by which student teachers learn about teaching philosophies and how they transfer this knowledge to their actual teaching. Other philosophical perspectives should also be explored through research to gain a better understanding of the experiential framework as a teaching tool for theoretical knowledge.

Additionally, quantitative studies could be done to measure the extent to which the experiential approach could be used in learning about more abstract content such as philosophy and if the gains are actually greater in comparison to a traditional teaching through lectures. If it was to be the case, it would then be possible to make recommendations to directors of programs in educational trainings to move towards a more practical approach with the goal of increasing teachers' competence and students' knowledge.

\section{Conclusion}

From our inquiry, we have some concluding thoughts. First, we observed that it is possible to do experiential teaching and learning of philosophy, and that it needs to work hand in hand with practice to create meaningful learning. Additionally, we saw that subjects traditionally considered purely intellectual, such as the philosophy of education, can and must relate to the reality of the practitioner. This is a crucial element to improve both the educational practice of philosophy, and its awareness and relevance to the next generation of educators. Second, we witnessed how music can connect with visual arts, how they can complete each other and how through the creation of these soundscapes, one is offered freedom to create without the limits and possible fear that formal training and traditional music notation can induce. We also noted that by giving the participants the opportunity to be at the heart of this practice and by having them live this philosophical experience, we came to the realisation that "There are no more teachers, just a community of learners" (Schafer, 1975a). Finally, we noted an increase in the participants' consciousness of the sounds that surrounds us. These sounds can have a powerful impact on our everyday life, generate stress and anxiety and participate in what Schafer calls "sound pollution" (Schafer, 1967). But at the same time, these surrounding sounds become the soundtrack of our life and construct our memories and who we are. As Schafer said: "Portions of the world symphony have already been played” (Schreiber, 2014).

As a final element, we would like to offer this quote by Schafer, and how it was echoed by one of our participants.

My approach has been to treat the world soundscape as a huge macrocosmic 
composition which deserves to be listened to as attentively as a Mozart symphony. Only when we truly learn how to listen, can we make effective judgements about the world soundscape (Schafer, 1973: p. 32).

Closing our eyes and experiencing a visual representation to a beautiful composed piece or the sounds of an environment dear to us is truly awakening yet, in other words, a spiritual experience (Generalist Teacher).

\section{Conflicts of Interest}

The authors declare no conflicts of interest regarding the publication of this paper.

\section{References}

Canadian National Art Center (2016). Listen up, Canada! Inspired by the Music and Pedagogy of Canadian Composer R. Murray Schafer. Ottawa: National Arts Center of Canada.

Cloutier, R., Gosselin, P., \& Tap, P. (2005). Psychologie de l'enfant (2nd ed.). Montreal: Chenelière Éducation.

Eisenberg, N., \& Fabes, R. A. (1998). Prosocial Development. In W. Damon, \& N. Eisenberg (Eds.), Handbook of Child Psychology: Fifth Edition, Vol. 3: Social, Emotional and Personality Development (pp. 701-778). Hoboken, NJ: John Wiley \& Sons.

Elliot, D. (1995). Music Matters: A New Philosophy of Music Education. New York: Oxford University Press.

Elliot, D., \& Silverman, M. (2014). Music Matters: A Philosophy of Music Education (2nd ed.). New York: Oxford University Press.

Gardner, H., Phelps, E., \& Wolf, D. P. (1990). The Roots of Adult Creativity in Children's Symbolic Products. In C. N. Alexander, \& E. J. Langer (Eds.), Higher Stages of Human Development (pp. 79-96). Oxford: Oxford University Press.

Gilmor, A. L. (2015). Raymond Murray Schafer. http://thecanadianencyclopedia.ca/en/article/r-murray-schafer

Harris, M. B. (1970). Reciprocity and Generosity: Some Determinants of Sharing in Children. Child Development, 41, 313-328. https://doi.org/10.2307/1127034

Jorgensen, E. (1997). In Search of Music Education. Urbana, IL: University of Illinois Press.

Kern, P. (2007). Surrounded by Soundscapes: An Afternoon Talk with R. Murray Schafer. Music Therapy Today, 8, 294-300. http://musictherapyworld.net

Kolb, A. Y., \& Kolb, D. A. (2005). Learning Styles and Learning Spaces: Enhancing Experiential Learning in Higher Education. Academy of Management Learning \& Education, 4, 193-212. https://doi.org/10.5465/amle.2005.17268566

Kolb, A. Y., \& Kolb, D. A. (2017). The Experiential Educator: Principles and Practices of Experiential Learning. Experience Based Learning Systems.

Kolb, D. A. (1984). Experiential Learning: Experience as the Source of Learning and Development. Englewood Cliffs, NJ: Prentice-Hall, Inc.

Kolb, D. A., \& Fry, R. (1975). Toward an Applied of Experiential Learning. In C. Cooper (Ed.), Studies of Group Process (pp. 33-57). New York: Wiley.

Reimer, B. (1970). A Philosophy of Music Education. Englewood Cliffs, NJ: Prentice Hall.

Reimer, B. (2003). A Philosophy of Music Education, Advancing the Vision (3rd ed.). 
Upper Saddle River, NJ: Prentice Hall.

Russell-Bowie, D. (2013). Mission Impossible or Possible Mission? Changing Confidence and Attitudes of Primary Preservice Music Education Students Using Kolb's Experiential Learning Theory. Australian Journal of Music Education, 2, 46.

Rutherford, S. (2014). Murray Schafer's Creative Music Education Relevant in the 21st Century? Canadian Music Educator, 55, 16-20.

Schafer, M. (1973). Further Thoughts on Music Education. Australian Journal of Music Education, 13, 3.

Schafer, R. M. (1967). Ear Cleaning: Notes for an Experimental Music Course. Toronto: Clark \& Cruickshank.

Schafer, R. M. (1969). The New Soundscape: A Handbook for the Modern Music Teacher. New York: Associated Music Publishers.

Schafer, R. M. (1975a). The Graphics of Musical Thoughts. In I. Bontinck, \& O. Brusatti (Eds.), Festschrift Kurt Blaukopf (pp. 120-141). Wien: Universal Edition.

Schafer, R. M. (1975b). The Rhinoceros in the Classroom. Toronto: Universal Edition.

Schafer, R. M. (1977). The Tuning of the World. New York: Knopf.

Schafer, R. M. (1986). The Thinking Ear: Complete Writings on Music Education. Toronto: Arcana Editions.

Schreiber, E. (2014). "Silence Filled with Sound": Spatial and Visual Metaphors in Raymond Murray Schafer's Idea of Soundscape. In P. Lang (Ed.), Visual Learning: Power of the Image: Emotion, Expression, Explanation (pp. 131-142). Frankfurt am Main: Internationaler Verlag der Wissenschaften.

Staub, E., \& Sherk, L. (1970). Need for Approval, Children's Sharing Behavior, and Reciprocity in Sharing. Child Development, 41, 243-252. https://doi.org/10.2307/1127403

Van Manen, M. (1997). Researching Lived Experience: Human Science for an Action Sensitive Pedagogy (2nd ed.). London: The Althouse Press.

Warneken, F., \& Tomasello, M. (2006). Altruistic Helping in Human Infants and Young Chimpanzees. Science, 311, 1301-1303. https://doi.org/10.1126/science.1121448

Wheeler, T. R. (2006). Toward a Framework for a New Philosophy of Music Education: Løgstrup as Synergy between the Platonic and Aristotelian Perspectives in the Music Education Philosophies of Bennett Reimer and David Elliott. Doctoral Dissertation, Denton, TX: University of North Texas.

Wrightson, K. (2000). An Introduction to Acoustic Ecology. Soundscape: The Journal of Acoustic Ecology, 1, 10-13.

http://www.econtact.ca/5_3/wrightson_acousticecology.html 